\author{
Katarina Rasulić \\ University of Belgrade \\ Faculty of Philology \\ Belgrade, Serbia
}

\title{
HIGH EXPECTATIONS AND LOW BLOWS: ANTONYMY AND DYNAMIC MEANING CONSTRUCTION $^{* *}$
}

\begin{abstract}
This paper, set against the theoretical background of cognitive linguistics, explores the cognitive potential of the lexical-semantic relation of antonymy from the perspective of dynamic meaning construction. Ten pairs of English canonical antonyms (high/low, long/short, broad/narrow, deep/shallow, thick/thin, heavy/ light, hard/soft, large/small, fast/slow, hot/cold) are examined with respect to the ways in which the relation of meaning oppositeness holding between their members is dynamically activated under semantic extension, paradigmatically and syntagmatically, in semantically creative instances of use. The analysis highlights the following aspects of such dynamic meaning construction: (i) the availability of dormant antonym senses for context-induced activation (e.g. shallow trouble); (ii) the modifiability of idiomatic expressions through antonym substitution (e.g. The bigger they come, the harder they fall > The bigger they come, the softer they fall); (iii) the syntagmatic co-occurrence of antonyms whose extended senses belong to different conceptual domains (e.g. High hopes in low places). The theoretical considerations pertain to the cognitive entrenchment of antonymy as a powerful trigger of dynamic meaning construction.
\end{abstract}

Key words: antonymy, semantic extension, dynamic meaning construction, cognitive linguistics

\footnotetext{
E-mail address: ekv@eunet.rs

** To Prof. Boris Hlebec, whose pioneering work in the field of lexical semantics at the English Department, Faculty of Philology, University of Belgrade, provides lasting inspiration for many generations of students and scholars.
} 


\section{Introduction}

Antonymy is arguably the most extensively studied lexical semantic relation - and for good reasons, which can be summarized by Lyons's (1977: 277) observation that "antonymy reflects or determines what appears to be a general human tendency to categorize experience in terms of dichotomous contrast". The cognitive salience of antonymy has long been evident in psycholinguistic research, which shows, among other things, that a word with an opposite meaning is the most common response in free word association tasks, that antonym pairs are identified at a faster rate than word pairs related in other ways, and that the ability to match opposites develops earlier in childhood than is the case with other semantic relations (cf. Deese 1965, Postman and Keppel 1970, Herrmann et al. 1979, Gross, Fischer and Miller 1989, Landis, Herrmann and Chaffin 1987). Parallelly, linguistic treatments of antonymy appear to increase in number and scope, shifting from structuralist and logical-semantic perspectives to cognitively and pragmatically oriented usage-based accounts, and opening up new lines of research (cf. Lyons 1977, Lehrer 1985, 2002, Cruse 1986, 2004, Justeson and Katz 1991, 1992, Mettinger 1994, Cruse and Togia 1995, Fellbaum 1995, Willners 2001, Jones 2002, Murphy 2003, 2010, Croft and Cruse 2004, Paradis and Willners 2011, Jones et al. 2012, Kostić 2013, Rasulić 2016).

This paper explores the cognitive potential of antonymy from the perspective of dynamic meaning construction. Set against the theoretical background of cognitive linguistics, the analysis integrates insights pertaining to the dynamic construal approach to meaning, conceptual mechanisms underlying semantic extension, constructional architecture of the language, and antonym co-occurrence in discourse. Specifically, ten pairs of English canonical antonyms (high/low, long/short, broad/ narrow, deep/shallow, thick/thin, heavy/light, hard/soft, large/small, fast/slow, hot/cold) are examined with respect to the ways in which the relation of semantic oppositeness holding between their members is dynamically activated under semantic extension, both paradigmatically and syntagmatically, in semantically creative instances of use. The paper is structured as follows: the theoretical and methodological coordinates are provided in Sections 2 and 3, the results of the analysis are presented and discussed in Section 4, and the global findings and implications for further research are summarized in the concluding Section 5. 
Katarina Rasulić: High Expectations and Low Blows: Antonymy and Dynamic...

\section{Antonymy and semantic extension from a cognitive-linguistic perspective}

To begin with, it is worth recalling Ullmann's (1957: 117) oft-quoted dictum that "polysemy is the pivot of semantic analysis". This is also valid with respect to antonymy, since, like other paradigmatic lexical semantic relations, antonymy actually relates some, not necessarily all senses of one lexeme to another. ${ }^{1}$ Hence, for instance, a single lexeme can (and often does) have more than one antonym corresponding to its different senses (e.g. hard : soft (mattress) / easy (task) / light (blow) / mild (winter)), and sometimes it is even possible for different senses of the same lexeme to be opposite to each other (e.g. a fast car : a fast grip).

The point of interest here is the aspect of antonymy-polysemy interface which concerns asymmetries in the extended senses of the two members of an antonym pair. Namely, it is not uncommon for one member of an antonym pair to have richer semantic extension than the other (for instance, high, deep, fast are more polysemous than their counterparts low, shallow, slow). Thereby, as observed by Lehrer (2002), and illustrated by her example in (1), the antonym relation holding between the basic and frequent senses of two lexical items can be contextually extended to senses lacking in one pair member.

(1) He traded in his hot car for a cold one.

The extended sense of hot 'illegally acquired' is illustrative of the asymmetry in the semantic extension of antonym pair members, since it is not parallelled by the corresponding conventionalized opposite extended sense of cold. But when cold is directly contrasted with this particular sense of hot

1 Cf. Lyons's (1977) term paradigmatic sense relations, where sense pertains to the aspect of lexical meaning which relates a linguistic expression to other expressions in the language system, while denotation relates a linguistic expression to a set of potential referents in the external world. Cruse (1986: 76) introduces the term lexical unit for "the union of a lexical form and a single sense" and characterizes a lexeme as "a family of lexical units", emphasizing that semantic relations hold between lexical units, not between lexemes. Although paradigmatic lexical semantic (sense) relations are often discussed with regard to the primary senses of the lexemes involved, their intertwinedness with multiple senses of lexical items always needs to be kept in sight. Generally, the more senses of two lexemes are related in a particular way, the stronger the given lexical semantic relation between them; and vice versa, the more polysemous a lexeme is, the less likely it is that a particular semantic relation will hold for all of its senses (for further considerations regarding the interface between polysemy and paradigmatic lexical semantic relations, cf. Rasulić 2016). 
in context, as in (1), cold is effortlessly interpreted as 'legally acquired', due to the projection of the antonym relation.

This phenomenon is in line with the cognitive-linguistic approach to meaning, which explicitly acknowledges the encyclopedic nature of meaning, the dynamic interaction between semantic and conceptual structure, the pervasiveness of polysemy, and the principles of prototypicality and gradience in linguistic categories (for a comprehensive overview, cf. Geeraerts and Cuyckens 2010). A variant thereof which is of particular relevance for the study of antonymy is the dynamic construal approach to meaning, proposed by Croft and Cruse (2004: 97), who argue that "neither meanings nor structural relations are specified in the lexicon, but are construed 'on-line', in actual situations of use". On this view, lexical semantic relations in general and antonymy in particular are treated as conceptual and contextual construals, rather than as fixed structural relations between particular linguistic items. Paradis (2011) further elaborates the dynamic construal approach to antonymy, based on textual and psycholinguistic data. She argues that "antonymy is a binary construal of comparison in which the contentful dimension is divided by a bounded configuration" (Paradis 2011: 41), i.e. that form-meaning pairings are construed as antonyms when they are used in binary contrast in discourse, whereby antonym construals range from highly conventionalized ones (e.g. neither good nor bad) to strongly contextually motivated ones (e.g. I prefer calm waters to flowing waters), with the former perceived as better antonym pairings than the latter.

The gradient nature of goodness of antonym pairings, verified in psycholinguistic research (Hermann et al. 1979), is reflected in Murphy's (2003) notion of antonym canonicity as the degree to which antonyms are semantically related (based on the principle of minimal difference) and conventionalized in language as antonym pairs without reference to context. In a discussion related to the projection of antonym relation to extended senses illustrated by the example (1) (He traded in his hot car for a cold one), Murphy (2003: 34) notes that "the stability of some such antonym pairs across senses and contexts is evidence that those antonymic pairings are canonical". ${ }^{2}$

2 Cf. also Paradis, Willners and Jones (2009), who combine corpus-linguistic and experimental methodology and find that canonical antonyms can be diagnosed through textual co-occurrence, individual goodness-of-opposition ratings, and elicitation evidence. 
Within cognitive linguistics, lexical semantic extension is generally viewed as one of the multifaceted (linguistic and extra-linguistic) manifestations of the underlying conceptual mapping mechanisms, the most prominent of which are conceptual metaphor and metonymy (as expounded in the seminal account by Lakoff and Johnson 1980; see also Lakoff 1993, Panther and Radden 1999, Kövecses 2002). In brief, conceptual metaphor involves mapping across different domains, whereby a target domain is conceptualized in terms of a source domain (e.g. MORE IS UP, INTENSITY IS HEAT, IMPORTANCE IS SIZE), and conceptual metonymy involves mapping within a single domain, whereby one concept serves as a vehicle to mentally access a target concept within the same domain (e.g. BODY PART FOR PERSON, AUTHOR FOR HIS WORK, TIME/PLACE FOR EVENT).

With regard to metaphorical semantic extension, Deignan (2005: 169-192) examined paradigmatic sense relations in source and target domains using the Bank of English corpus data. For antonymy in particular, she analyzed English terms from the source domains of TEMPERATURE and LIGHT/DARKNESS, and found that the antonym relation is not consistently mapped in the target domains. The established inconsistencies pertain to different conceptual or linguistic aspects of metaphorical extension, such as different target domains (e.g. most metaphorical uses of light are associated with knowledge, while most metaphorical uses of dark are associated with unhappiness), collocational preferences highlighting different aspects of a target domain (e.g. both hot and cold extend their meanings to the sexual domain, but hot tends to collocate with words referring to texts and images, meaning 'sexually explicit', while cold rather collocates with words referring to people, meaning 'uninterested in sex'), uneven distribution across word classes (e.g. metaphorical light tends to be nominal, while metaphorical dark tends to be adjectival), etc. In contrast to such inconsistencies in temperature and light/darkness metaphors, Deignan (2005) found that semantic relations do get preserved in cases of metaphorical mappings ARGUMENT IS WAR and COMPLEX ABSTRACT SYSTEMS ARE PLANTS. Approaching the issue of the consistence of semantic relations in source and target domains from the standpoint of the nature of mappings, she concluded that the observed differences may be accounted for in terms of whether the mapping involved is pure metaphor (as is the case with war and plant metaphors) or metonymy-based metaphor (as is the case with temperature and light/darkness metaphors). 
In this paper, the issue of (in)consistence of antonym relation under asymmetric semantic extension will be addressed from the dynamic construal standpoint, with the aim to explore the projectability and activatability of antonym relation in semantically creative instances of use. ${ }^{3}$

\section{Scope of analysis}

The antonym pairs selected for analysis include the following gradable adjectives: high/low, long/short, broad/narrow, deep/shallow, thick/thin, heavy/light, hard/soft, large/small, fast/slow, hot/cold. They belong to canonical antonyms and are also representative of the central variety of antonymy (variously termed in the pertinent literature as 'scalar antonymy', 'gradable antonymy', 'contrary antonymy', 'antonymy proper' or just 'antonymy'), which is typical of gradable adjectives and involves the partitioning of the underlying semantic dimension in a more-less fashion, with a neutral middle ground in between, so that antonym pair members yield unilateral negative entailments (e.g. If something is high, then it is not low; If something is not high, it is not necessarily low - it may be neither high nor low). ${ }^{4}$

With respect to Cruse and Togia's (1995) and Croft and Cruse's (2004: 169-185) cognitive-linguistic treatment of antonymy based on the image schema of SCALE, the selected antonym pairs belong to both monoscalar

3 The notion of semantic creativity is broadly understood as the capacity of speakers to produce semantic content beyond the ordinary and conventional, as is the case with humour, irony, metaphors, and other higher-order language products which involve the activation and processing of multiple alternative meanings (cf. Kennet, Anaki and Faust (2014); for a comprehensive survey of different perspectives on the relationship between language and creativity, see Jones R. (2016)).

4 Notably, Lyons (1977) and Cruse (1986) reserve the term antonymy only for this central type of semantic oppositeness, treating instances of other types (complementary, relational etc.) more broadly as opposites. For the broader use of the term antonymy with reference to different types of meaning oppositeness, and the varying terminological solutions, cf. e.g. Kempson 1977, Leech 1981, Palmer 1981, Murphy 2003, Geeraerts 2010, Hlebec 2010, Rasulić 2016. Here it should also be emphasized that the lexical semantic relation of antonymy, although found across different word classes, is particularly characteristic of adjectives, as amply evidenced not only in the theoretical-descriptive literature but also in psycholinguistic and corpus-linguistic research (e.g. Deese 1965, Fellbaum 1998, Jones et al. 2012). 
(e.g. high/low) and biscalar (e.g. hot/cold) systems. ${ }^{5}$ Thereby the selection reflects the predominance of the former type, in which the term highlighting the upper part of the underlying scale yields a neutral how-question and both members yield neutral comparatives (e.g. How high is it? >>It may be high or low, or neither vs. How low is it? >> It is low; X is higher than $Y$, but both are low : $X$ is lower than $Y$, but both are high), as opposed to the latter type, in which both members yield questions and comparatives committed to one part of the scale (e.g. How hot is it? >> It is hot: How cold is it? >>It is cold; $X$ is hotter than $Y>>$ Both $X$ and $Y$ are hot $: X$ is colder than $Y>>$ Both $X$ and $Y$ are cold).

Furthermore, and particularly importantly for the present analysis, all the selected adjectives are notably polysemous, with the antonym pair members manifesting asymmetries in semantic extension and collocational preferences, as indicated in (1) above and further illustrated in (2):

(2) For example, we say 'deep trouble' but 'shallow trouble' is not acceptable.

(Peter Watkins (2005): Learning to Teach English, Delta Publishing, p. 41)

The analysis consists of three parts. The first two parts deal with the paradigmatic projectability of antonym relation under semantic extension, and the third part deals with the syntagmatic co-occurrence of antonyms in senses belonging to different conceptual domains. Throughout the analysis, the antonym pair members which denote the upper part of the underlying scales serve as the starting point, since they generally tend to manifest richer semantic extension than their counterparts (as evident from the pertinent lexicographic resources, both in the number of listed senses and in the number of idiomatic expressions in which antonym pair members occur). The applicability of the findings in the opposite direction is tested using one monoscalar and one biscalar antonym pair (low/high and cold/hot respectively).

The analysis is qualitative. The data has been collected through Internet (Google) search, featuring examples attested in actual language

This treatment largely relates to the broader notions of markedness and polarity (cf. Lyons 1977, Bolinger 1977, Lehrer 1985, Cruse 1986, Rasulić 2016), but it brings the cognitively motivated scalar properties to the foreground, as particularly transpires in Cruse and Togia's (1995) and Croft and Cruse's (2004) terminological distinction between supra and sub antonym pair members in monoscalar systems. 
use. ${ }^{6}$ The lexicographic resources used for semantic glossing include the following: Oxford English Dictionary (http://www.oed.com/), MerriamWebster Dictionary (https://www.merriam-webster.com/), and The Free Dictionary by Farlex (https://www.thefreedictionary.com/).

The first part of the analysis examines the projection of antonym relation to extended senses which are 'missing' in one of the antonym pair members. Specifically, the analysis focuses on the asymmetrically extended senses of the antonym pair members listed in (3), whereby the semantic extension asymmetries have been established with a view to the pertinent theoretical-descriptive accounts provided by Hlebec (1979) /dimensional adjectives/, Rasulić (2004) /verticality adjectives/ and Rasulić (2015) /temperature adjectives/, and taking into account the fact that collocations constitute an important source of information for determining the semantic content of a word, as particularly demonstrated in the collocational method developed by Hlebec $(1998,2008,2010)$.

(3) high priest : ? low priest

long guess : ? short guess

broad humour : ? narrow humour

deep trouble: ? shallow trouble

thick accent : ? thin accent

heavy with child : ? light with child

hard life : ? soft life

large view : ? small view

fast woman : ? slow woman

hot battle : ? cold battle

low cunning : ? high cunning

cold statistics : ? hot statistics

The second part of the analysis is concerned with the projection of antonym relation with regard to the modifiability of idiomatic expressions. This aspect is included since idiomatic expressions are generally characterized by a high degree of conventionalization, lexico-syntactic fixedness and non-compositional semantic unity (cf. Mel'čuk 1995,

6 For the benefits and shortcomings of web-based corpus research into linguistic phenomena, see e.g. Kilgarriff and Grefenstette (2003), and, with respect to antonymy, Jones et al. (2007). Given the qualitative nature of the present analysis, the web-based research proves beneficial insofar that it provides insight into infrequent but nevertheless noteworthy instances of semantically creative language use. 
Moon 1998, Gries 2008), which makes them a particularly good testing ground for the projectability of antonym relation. Corpus linguistics has shown that the "so-called 'fixed phrases' are not in fact fixed" (Sinclair 1996: 83), and the issue of phraseological variability has been addressed within different theoretical frameworks (e.g. Moon 1998, Wray 2002, Philip 2008), including cognitive linguistics (e.g. Langlotz 2006, Rasulić 2010). Examining this phenomenon from the perspective of construction grammar (Goldberg 2006), a cognitive-linguistic theory which postulates the constructional architecture of language in terms of idiosyncratic formmeaning correspondences, Rasulić (2010) found that the so-called fixed expressions manifest inherent constructional dynamism that is variously exploited to create novel meanings, whereby a noticeable aspect of constructional variation involves lexical substitution triggered by semantic oppositeness (ranging from antonymy between the replaced and the novel element to the contrast conditioned by the overall meaning of the host expression), as illustrated by the examples in (4):

(4) First come, last served (< First come, first served) Once bitten, never shy ( $<$ Once bitten, twice shy)

The focus here is on the substitutability of antonyms in idiom modification. The analysis includes the idiomatic expressions listed in (5). In terms of Fillmore, Kay and O'Connor's (1988) classification, which is widely acknowledged in the pertinent cognitive-linguistic literature, all of them belong to substantive (lexically filled) idioms, but differ with respect to degrees of non-compositionality (cf. as honest as the day is long /encoding, i.e. interpretable based on the knowledge of constituent lexical meanings and grammar, but not predictable/ : pull a fast one /decoding, i.e. uninterpretable regardless of the knowledge of constituent lexical meanings and grammar, hence also unpredictable/), and conformity to general syntactic rules (cf. pull a fast one /grammatical/ : by and large /extragrammatical/).

(5) (as) high as a kite

(as) honest as the day is long

in broad daylight

go off the deep end

(as) thick as thieves

make heavy weather of something

The bigger they come, the harder they fall 
by and large

pull a fast one

go like hot cakes

low blow

give someone the cold shoulder

Finally, the third part of the analysis involves the syntagmatic axis. This aspect is included because ample evidence from corpus linguistics (cf. Justeson and Katz 1991, 1992, Mettinger 1994, Fellbaum 1995, Willners 2001, Jones 2002, Jones et al. 2012, Kostić 2013) shows that, in addition to the paradigmatic relatedness, antonyms manifest noteworthy syntagmatic affinity, readily attracting each other in text/discourse, whereby "antonyms not only co-occur significantly more often in the same sentence than chance predicts, but also significantly more often than other semantically related word pairs such as synonyms or hyponyms" (Jones et al. 2012: 26). ${ }^{7}$ The focus is on the syntagmatic co-occurrence of antonyms under semantic extension, i.e. on the co-occurrence of their extended senses which belong to different conceptual domains, as illustrated in (6), where the coordinated senses of high and low are motivated by metaphorical mappings of the vertical dimension into abstract target domains of intensity and morality respectively.

(6) She tells a fascinating tale [...] of high expectations and low blows. (https://ethanjonesbooks.wordpress.com/2013/03/20/deadlystakes-by-j-a-jance/)

In this regard, the following extended senses and the corresponding collocational combinations of the pertinent antonym pair members are taken into account:

(7) high hopes...

long odds...

broad minds...

7 Thereby converging corpus evidence shows that antonyms tend to co-occur in characteristic lexico-grammatical frames, serving different discourse functions. The two most prominent categories elaborated in the above-mentioned studies include (i) coordinated (inclusive) antonymy, which covers the whole semantic dimension along which the antonym pair contrasts and neutralizes the opposition, typically occurring in conjunctive or disjunctive combinations (e.g. (both) $X$ and $Y$, (either/whether) $X$ or $Y$ ), and (ii) ancillary antonymy, which highlights or creates another contrast within a sentence, typically in a parallel syntactic structure (e.g. Success makes men proud; failure makes them wise). 
deep secrets...

thick accent...

heavy heart...

hard evidence...

large role...

fast minds...

hot topics...

low budget...

cold reality...

\section{Results and discussion}

\subsection{Dormant antonym sense activation}

In all the instances examined, the paradigmatic antonym relation turns out to be projectable in order to activate an extended sense which is not commonly featured by one pair member (here referred to as 'dormant sense'), as shown in Table 1.

\begin{tabular}{|c|l|l|}
\hline Ex. & $\begin{array}{l}\text { Asymmetrically } \\
\text { extended senses }\end{array}$ & \multicolumn{1}{c|}{ Dormant antonym sense activation } \\
\hline (8) & $\begin{array}{l}\text { high priest } \\
\text { 'chief priest / } \\
\text { chief exponent of a } \\
\text { doctrine or an art' } \\
: \text { ? low priest } \\
\text { sigh. They had been there for years, and took turns at being the } \\
\text { high one. ... They were playing Cripple Mr. Onion on the high } \\
\text { altar... } \\
\text { "Now", said the High Priest, "What was the stake?" } \\
\text { "Two pebbles", said the low priest. } \\
\text { (Terry Pratchett: Reaper Man, 2007, EPub Edition, HarperCollins } \\
\text { e-books. } \\
\text { https://www.ebooks.com/en-rs/305454/reaper-man/pratchett-terry/) }\end{array}$ \\
\hline (9) & $\begin{array}{l}\text { Traditionally, only two priests ever went into the innermost } \\
\text { 'extending beyond } \\
\text { what is known' } \\
: ? \text { short guess }\end{array}$ & $\begin{array}{l}\text { If, for a problem } \text { p, we can generate a "short guess" and check } \\
\text { the guess efficiently, then } p \text { belongs to the class NP. } \\
\text { (Gopalakrishnan, G.L. (2006): Computation Engineering: Applied } \\
\text { Automata Theory and Logic. New York: Springer. } \\
\text { https://books.google.rs/books?isbn=0387325204) }\end{array}$ \\
\hline
\end{tabular}




\begin{tabular}{|c|c|c|}
\hline (10) & $\begin{array}{l}\text { broad humour } \\
\text { 'coarse, indecent' } \\
: \text { ? narrow } \\
\text { humour }\end{array}$ & $\begin{array}{l}\text { It's the kind of broad humour that's just narrow enough to be } \\
\text { funny. } \\
\text { (https://hookedonfilmwa.wordpress.com/tag/madison-iseman/) }\end{array}$ \\
\hline (11) & $\begin{array}{l}\text { deep trouble } \\
\text { 'very intense or } \\
\text { extreme' } \\
: ? \text { shallow } \\
\text { trouble }\end{array}$ & $\begin{array}{l}\text { „You have to love life when you're in really deep trouble," said poet } \\
\text { Robin Blaser. So what about if, on the other hand, you're in only } \\
\text { shallow trouble? } \\
\text { (https://www.freewillastrology.com/horoscopes/20080731.html) }\end{array}$ \\
\hline (12) & $\begin{array}{l}\text { thick accent } \\
\text { 'strongly marked/ } \\
\text { distinct' } \\
: ? \text { thin accent }\end{array}$ & $\begin{array}{l}\text { His accent was thin, but not unnoticeable. } \\
\text { (https://www.fanfiction.net/s/1740767/1/Devil-May-Not-Cry) }\end{array}$ \\
\hline (13) & $\begin{array}{l}\text { heavy with child } \\
\text { 'pregnant, esp. } \\
\text { approaching } \\
\text { parturition' } \\
: \text { ? light with } \\
\text { child }\end{array}$ & $\begin{array}{l}\text { Amongst the flock was Frau Mary who was light with child... } \\
\text { (http://www.h5hashers.org.uk/words/oldWords/2014/1237.htm) }\end{array}$ \\
\hline (14) & $\begin{array}{l}\text { hard life } \\
\text { 'difficult to bear/ } \\
\text { causing suffering' } \\
: \text { ? soft life }\end{array}$ & $\begin{array}{l}\text { Why do I sometimes wish I had a hard life? ... [To] prove to people } \\
\text { you can survive a hard life as easily as you have survived your } \\
\text { "soft" life. } \\
\text { (https://www.quora.com/Why-do-I-sometimes-wish-I-had-a- } \\
\text { hard-life) }\end{array}$ \\
\hline (15) & $\begin{array}{l}\text { large view } \\
\text { 'comprehensive/ } \\
\text { wide-ranging' } \\
: \text { ? small view }\end{array}$ & $\begin{array}{l}\text { On this subject we have to take a large view, but in all parties there } \\
\text { are some who take a small view. } \\
\text { (https://hansard.parliament.uk/commons/1924-02-22/debates/ } \\
\text { 034c037a-5584-4604-a93c-8bed181a02f6/OrdersOfTheDay) }\end{array}$ \\
\hline (16) & $\begin{array}{l}\text { fast woman } \\
\text { 'sexually } \\
\text { promiscuous' } \\
\text { :? slow woman }\end{array}$ & $\begin{array}{l}\text {...speaking as a slow woman (as opposed to a "fast woman", I } \\
\text { guess!), I don't tend to be surrounded by men... } \\
\text { (https://forums.runnersworld.co.uk/discussion/104143/bupa- } \\
\text { great-south-run/p9) }\end{array}$ \\
\hline (17) & $\begin{array}{l}\text { hot battle } \\
\text { 'fierce, intense' } \\
\text { : ? cold battle }\end{array}$ & $\begin{array}{l}\text { Seems like there's going to be a battle between Nivix and Sonic... } \\
\text { It's not a hot battle, it's like a cold battle... } \\
\text { (https://www.deviantart.com/nivixthelucario/art/Hedgehog- } \\
\text { Rumble-751918247) }\end{array}$ \\
\hline
\end{tabular}


Katarina Rasulić: High Expectations and Low Blows: Antonymy and Dynamic...

\begin{tabular}{|c|l|l|}
\hline (18) & $\begin{array}{l}\text { low cunning } \\
\text { 'unscrupulous/ } \\
\text { morally } \\
\text { reprehensible' } \\
\mathbf{2} \text { ? high cunning }\end{array}$ & $\begin{array}{l}\text { You hear a lot about low cunning but very little about high } \\
\text { cunning. That's because high cunning is perpetrated by people } \\
\text { so above suspicion that you don't even notice it. } \\
\text { (Guy Browning: How to... be cunning, The Guardian, 19 July 2008 } \\
\text { https://www.theguardian.com/lifeandstyle/2008/jul/19/ } \\
\text { healthandwellbeing5) }\end{array}$ \\
\hline (19) & $\begin{array}{l}\text { cold statistics } \\
\text { 'objective/not } \\
\text { affected by } \\
\text { emotion' : } \\
\text { : ? hot statistics }\end{array}$ & $\begin{array}{l}\text { Fixed recurring data and temporary 'hot' statistics } \\
\text { (Bodelsson et al. (2012): Research library statistics: For whom and } \\
\text { for what purpose? In: New Trends in Qualitative and Quantitative } \\
\text { Methods in Libraries (eds. A. Katsirikou, C. Skiadas), 315-322. } \\
\text { https://books.google.rs/books?isbn=9814350303) }\end{array}$ \\
\hline
\end{tabular}

Table 1. Instances of dormant antonym sense activation

Namely, despite the conventionalized asymmetry of semantic extension and the corresponding asymmetry in collocational combinations of the observed antonym pair members, the projection of the cognitively entrenched antonym relation proves to be context-inducible for the purpose of highlighting direct contrast in particular instances of use, activating in one antonym pair member a dormant sense which may not be specified in the lexicon but is nevertheless available for dynamic on-line construal. As can be seen in examples (18) and (19), included to check whether the antonym relation can be projected from both the upper and the lower end of the underlying scales, this kind of sense activation is possible in both directions.

Thereby, the activation of a dormant antonym sense can be (and often is) triggered by the explicit mention of its conventionalized counterpart within a proximal context, including but not limited to the same syntagmatic sequence (ex. 8, 10, 11, 14, 15, 16, 17, 18), which bears additional witness to the aforementioned tendency of antonyms to co-occur in discourse. At the same time, dormant antonym senses can also be activated without such immediate contextual triggering (ex. 9, 12, 13, 19). The spontaneous use of hedging markers (ex. 17) or quotation marks (ex. 9, 14, 19) signals the speaker's/writer's awareness of the unusualness of dormant sense activation. Highlighting the availability of the dormant antonym pole for versatile context-induced activation under semantic extension, these findings provide additional insight into the cognitive potential of antonymy for dynamic meaning construction. 


\subsection{Idiom modification through antonym substitution}

The cognitively entrenched antonym relation also turns out to be readily projectable when it comes to the modification of idiomatic expressions. As shown in Table 2, modification through antonym substitution has been verified for all the idiomatic expressions examined (across their varying degrees of semantic non-compositionality and syntactic conformity, and in both directions of the underlying scales).

\begin{tabular}{|c|c|c|}
\hline Ex. & $\begin{array}{c}\text { Idiomatic } \\
\text { expression }\end{array}$ & Modification through antonym substitution \\
\hline$(20)$ & $\begin{array}{l}\text { as high as a kite } \\
\text { 'very excited/ } \\
\text { strongly affected by } \\
\text { alcohol or drugs' }\end{array}$ & $\begin{array}{l}\text { Apparently he was on 'downer' drugs at the time. He was "as } \\
\text { low as a kite", paramedics claim. } \\
\text { (https://twitter.com/YouHadOneJ0B/status/11011- } \\
\text { 81503726182400) }\end{array}$ \\
\hline$(21)$ & $\begin{array}{l}\text { as honest as the } \\
\text { day is long } \\
\text { 'very honest' }\end{array}$ & $\begin{array}{l}\text { There are five refineries in Colombia apparently. I'm sure } \\
\text { government officials are as honest as the day is short. } \\
\text { (https://uk.advfn.com/stock-market/london/amerisur-AMER/ } \\
\text { share-chat?page }=3861 \& \text { xref }=\text { chatnav_i_3_b) }\end{array}$ \\
\hline$(22)$ & $\begin{array}{l}\text { in broad daylight } \\
\text { 'openly, when anyone } \\
\text { can see it' }\end{array}$ & $\begin{array}{l}\text { [News headline:] Man threatened shop staff with a knife in } \\
\text { broad daylight. } \\
\text { [Comment:] It could be worse, it could have been in narrow } \\
\text { daylight or worse again in the dark! } \\
\text { (https://www.thejournal.ie/http://www.thejournal.ie/ } \\
\text { man-threatened-shop-knife-armagh-1472370-May2014/ } \\
\text { ?embedpost=1472370\&width=300\&height=460) }\end{array}$ \\
\hline (23) & $\begin{array}{l}\text { go off the deep end } \\
\text { 'be irrationally carried } \\
\text { away/become unduly } \\
\text { excited or angry' }\end{array}$ & $\begin{array}{l}\text { I often say to those concerned about going off the deep end, } \\
\text { "Have you considered what happens to those who go off the } \\
\text { shallow end? } \\
\text { (http://www.dwillard.org/articles/individual/wide-awake) }\end{array}$ \\
\hline (24) & $\begin{array}{l}\text { (as) thick as thieves } \\
\text { 'having a close, intimate } \\
\text { friendship or alliance' }\end{array}$ & $\begin{array}{l}\text { Hi! We're Matt and Hannah, also known as Thin As Thieves. } \\
\text { (https://www.youtube.com/channel/UC3qVFdQV-BHEy0oY9- } \\
\text { pYoGew/about?disable_polymer=1) }\end{array}$ \\
\hline$(25)$ & $\begin{array}{l}\text { make heavy weather } \\
\text { of something } \\
\text { 'make something seem } \\
\text { more difficult than it } \\
\text { really is' }\end{array}$ & $\begin{array}{l}\text { Celtic made light weather of the first qualifying round of } \\
\text { the Champions League [...] } \\
\text { (https://www.ihateceltic.com/brendan-rodgers-remains- } \\
\text { optimistic-over-moussa-dembele\%E2\%80\%99s-injury) }\end{array}$ \\
\hline
\end{tabular}




\begin{tabular}{|c|c|c|}
\hline (26) & $\begin{array}{l}\text { The bigger they } \\
\text { come, the harder } \\
\text { they fall } \\
\text { 'those who are } \\
\text { important/powerful/ } \\
\text { influential lose more } \\
\text { when they fail' }\end{array}$ & $\begin{array}{l}\text { The bigger they come, the softer they fall: The size of } \\
\text { pharma companies and how vigorously they are prosecuted } \\
\text { (http://hcrenewal.blogspot.com/2014/11/the-bigger-they- } \\
\text { come-softer-they-fall.html) }\end{array}$ \\
\hline (27) & $\begin{array}{l}\text { by and large } \\
\text { 'generally, on the } \\
\text { whole' }\end{array}$ & $\begin{array}{l}\text { New York Apartment Interior Design: A New Apartment Interior } \\
\text { By and Small } \\
\text { (http://cremafriends.com/portfolio/) }\end{array}$ \\
\hline (28) & $\begin{array}{l}\text { pull a fast one } \\
\text { 'trick someone/engage } \\
\text { in a } \\
\text { deceitful practice' }\end{array}$ & $\begin{array}{l}\text { But when it came to the House Rules Committee, Minority } \\
\text { Leader Frank Dermody, D-Oakmont, who fears shrinkage even } \\
\text { more than George Costanza did, pulled a fast one. Or, more } \\
\text { accurately, he pulled a slow one. This process has gone on } \\
\text { longer than even PennDOT projects, and Mr. Dermody aimed to } \\
\text { delay it further by amending the bill. } \\
\text { (https://www.post-gazette.com/opinion/brian-oneill/2018/- } \\
\text { 09/30/Six-reps-turn-tail-to-deny-you-a-vote-on-the-size-of- } \\
\text { our-Legislature/stories/201809300131) }\end{array}$ \\
\hline (29) & $\begin{array}{l}\text { go like hot cakes } \\
\text { 'sell very quickly' }\end{array}$ & $\begin{array}{l}\text { The Hot Fudge Brownie one went like hot cakes and the Hot } \\
\text { Cake Sticky one went like cold cakes. } \\
\text { (https://www.lodgefarmholidaybarns.co.uk/2014/07/30/ } \\
\text { summer-sundays-are-for-ice-cream/) }\end{array}$ \\
\hline (30) & $\begin{array}{l}\text { low blow } \\
\text { 'unscrupulous attack/ } \\
\text { insult' }\end{array}$ & $\begin{array}{l}\text { - Anybody who gives such a low blow cannot be serious about } \\
\text { his political career if he still has it. } \\
\text { - Who cares, low blow or high blow - as long as the intention } \\
\text { is to bring about justice? } \\
\text { (https://sloone.wordpress.com/2007/07/05/indeed-well- } \\
\text { done-tian-chua/) }\end{array}$ \\
\hline (31) & $\begin{array}{l}\text { give somebody the } \\
\text { cold shoulder } \\
\text { 'ignore somebody/ } \\
\text { treat somebody in a } \\
\text { deliberately unfriendly } \\
\text { way' }\end{array}$ & $\begin{array}{l}\text { See a model giving the hot shoulder at the Christian Dior } \\
2011 \text { Resort show this weekend. } \\
\text { (https://www.glamour.com/story/32-sexy-new-tops-how-to- } \\
\text { show-s) }\end{array}$ \\
\hline
\end{tabular}

Table 2. Instances of idiom modification through antonym substitution 
Thereby, antonym substitution usually involves directly opposed senses of antonym pair members, with the meaning of the modified expression standing in contrast to the overall idiomatic meaning of the host expression, as, for instance, in (29), where both hot and cold evoke temperature senses, and go like hot cakes 'sell very quickly' is transformed into go like cold cakes 'sell very slowly'. But it may also be the case that the antonym substitute brings in a sense which is actually not directly opposed to the sense of its counterpart in the host expression, as, for instance, in (31), where cold in give someone the cold shoulder 'ignore somebody/ treat somebody in a deliberately unfriendly way' evokes the 'emotionally detached' sense (whose direct opposite is featured by warm, not hot), while hot in the modified expression give someone the hot shoulder evokes the 'sexually attractive' sense and is paired with the basic concrete sense of shoulder (with reference to models wearing sexy off-the-shoulder tops in a fashion show). As a result, the meaning of the modified expression does not actually stand in direct contrast to the overall idiomatic meaning of the host expression, but reflects a more complex dynamic construal, which involves the projection of the cognitively entrenched antonym relation under asymmetric semantic extension and the interplay between linguistic and encyclopedic knowledge as well as between literal and figurative interpretation. ${ }^{8}$

On the whole, the fact that antonymy is actively exploited in idiom modification in versatile ways provides additional evidence into the cognitive salience of this lexical-semantic relation and its rich potential for dynamic meaning construction. Modification through antonym substitution may be triggered by the explicit mention of the original idiomatic expression in the surrounding context (which is in line with the aforementioned tendency of antonyms to co-occur in discourse), as in $(22,23,28,29,30)$. But even without such explicit mention, the original idiomatic expression is paradigmatically discernible based on the stored linguistic knowledge, and the modified expression cannot be fully understood without mental reference to the original one. From the broader perspective of idiom modifiability, the data presented here corroborate the previously discussed

8 Here it should be noted that direct contrast to the overall idiomatic meaning of give someone the cold shoulder is also achievable through antonym substitution, whereby the pertinent antonym sense is provided by warm instead of hot, as in the following illustrative example: Of an Oxford character known for his false geniality, Bowra remarked that at their last meeting the man gave him "the warm shoulder" (https://www.weeklystandard. com/joseph-epstein/the-oxford-man). 
cognitive-linguistic findings concerning the constructional productivity of idiosyncratic form-meaning pairings, with fresh insight into the special role of antonymy in this regard.

\subsection{Syntagmatic co-occurrence of antonyms whose senses belong to different conceptual domains}

Finally, with particular regard to the syntagmatic dimension, the third part of the analysis highlights the tendency of canonical antonyms to co-occur in syntagmatic sequences not only in the directly opposite senses but also in the senses which belong to different conceptual domains, as shown in Table 3.

\begin{tabular}{|c|l|l|}
\hline Ex. & \multicolumn{1}{|c|}{ Co-occurring antonyms } & \multicolumn{1}{c|}{ Senses of co-occurring antonyms } \\
\hline (32) & $\begin{array}{l}\text { High hopes in low places } \\
\text { (Song title by End of Green) }\end{array}$ & $\begin{array}{l}\text { high 'intense' } \\
\text { low 'socially inferior' }\end{array}$ \\
\hline (33) & $\begin{array}{l}\text { Long odds for short hitters at Augusta } \\
\text { National } \\
\text { (Associated Press, April 4, 2007 } \\
\text { https://www.golfchannel.com/article/ } \\
\text { associated-press/long-odds-short-hitters- } \\
\text { augusta-national) }\end{array}$ & $\begin{array}{l}\text { long 'reflecting a low level of } \\
\text { probability' } \\
\text { short 'covering a small distance' }\end{array}$ \\
\hline (34) & $\begin{array}{l}\text { Broad minds and narrow } \\
\text { perspectives } \\
\text { (VP Digital, December 1, 2015 } \\
\text { https://thevoiceslu.com/2015/12/broad- } \\
\text { minds-and-narrow-perspectives/) }\end{array}$ & $\begin{array}{l}\text { broad 'liberal, tolerant' } \\
\text { narrow 'limited in scope' }\end{array}$ \\
\hline (35) & $\begin{array}{l}\text { Deep secrets, shallow relationships } \\
\text { (Blog Post STEEVAK Stuff and Stuff, } \\
\text { https://steevak.com/, September 21, } \\
\text { 2006) }\end{array}$ & $\begin{array}{l}\text { deep 'unknown, obscure' } \\
\text { shallow 'superficial, weak' }\end{array}$ \\
\hline
\end{tabular}




\begin{tabular}{|c|c|c|}
\hline (36) & $\begin{array}{l}\text { Mr Del Prete might conceivably play a street } \\
\text { Arab, but in a sophisticated role, with his } \\
\text { thick accent and thin talent, he has as } \\
\text { much charm as a broomstick with a smile } \\
\text { painted on it. } \\
\text { (Chris Tookey'sMovie Film Review Database: } \\
\text { "At Long Last Love" /1975/: John Simon, } \\
\text { National Review } \\
\text { http://www.movie-film-review.com/ } \\
\text { devfilm.asp?rtype=3\&id=890) }\end{array}$ & $\begin{array}{l}\text { thick 'strongly marked, distinct' } \\
\text { thin 'lacking substance or quality' }\end{array}$ \\
\hline (37) & $\begin{array}{l}\text { With a heavy heart and light wallet, I } \\
\text { said goodbye to Italy the next morning. } \\
\text { (Blog Post A Tepid Reception, } \\
\text { https://tepidreception.wordpress.com/, } \\
\text { June 20, 2010) }\end{array}$ & $\begin{array}{l}\text { heavy 'characterized by severe pain or } \\
\text { suffering' } \\
\text { light 'carrying little or no content/money' }\end{array}$ \\
\hline (38) & $\begin{array}{l}\text { Salisbury incident report: Hard evidence } \\
\text { for soft minds } \\
\text { (By Tyler Durden, Zero Hedge, March 30, } \\
2018 \text { https://www.zerohedge.com/) }\end{array}$ & $\begin{array}{l}\text { hard 'reliable, factual' } \\
\text { soft 'susceptible to influence' }\end{array}$ \\
\hline (39) & $\begin{array}{l}\text { Why your business relationships may hinge } \\
\text { on the large role of small talk } \\
\text { (https://www.getabstract.com/en/ } \\
\text { channels/small-talk/1359) }\end{array}$ & $\begin{array}{l}\text { large 'important, influential' } \\
\text { small 'casual, trivial' }\end{array}$ \\
\hline (40) & $\begin{array}{l}\text { Cities should be filled with fast minds } \\
\text { and slow streets. } \\
\text { (https://www.cyburbia.org/forums/ } \\
\text { threads/should-cities-convert-one-way- } \\
\text { streets-to-two-way.16076/) }\end{array}$ & $\begin{array}{l}\text { fast 'mentally alert' } \\
\text { slow 'characterized by lack of speed' }\end{array}$ \\
\hline (41) & $\begin{array}{l}\text { Hot topics and cold reactions in rugby } \\
\text { league } \\
\text { (https://www.theroar.com.au/- } \\
2011 / 07 / 15 / \text { hot-topics-and-cold- } \\
\text { reactions/) }\end{array}$ & $\begin{array}{l}\text { hot 'of great and immediate } \\
\text { interest' } \\
\text { cold 'reserved, unfriendly' }\end{array}$ \\
\hline (42) & $\begin{array}{l}\text { Hope you guys like the low budget but } \\
\text { high spirit of our birthday suprise... } \\
\text { (https://www.picdove.com/profile/ } \\
\text { zpin22) }\end{array}$ & $\begin{array}{l}\text { low 'small in amount' } \\
\text { high 'filled with joy and } \\
\text { excitement' }\end{array}$ \\
\hline
\end{tabular}


Katarina Rasulić: High Expectations and Low Blows: Antonymy and Dynamic...

(43) Cold reality of a hot investment

(June Arney, The Baltimore Sun, 25

October 2005

https://www.baltimoresun.com/news/bs-

xpm-2005-10-25-0510250084-story.html)

Table 3. Instances of co-occurring antonyms whose senses belong to different conceptual domains

Concurring with the previously discussed corpus-linguistic evidence of the syntagmatic affinity of antonyms, these findings provide further insight into the cognitive entrenchment of antonymy and its potential for dynamic meaning construction under semantic extension. Namely, the analysis shows that canonical antonyms readily attract each other across different conceptual domains, including the ones in which the extended senses of antonym pair members diverge asymmetrically (as, for instance, in (36): his thick (?thin) accent and thin (?thick) talent). The semantic extension profiled in the attested examples is predominantly metaphorical, but it may also involve concrete domains and metonymic mappings, as in (33), where the 'covering a small distance' sense of short in short hitters involves the metonymic transfer from an action-related property to the person involved in the action. With regard to metaphorical extension, the data presented here are akin to the notions of topic-triggered and situationally-triggered metaphors discussed by Koller (2004) and Semino (2008), adding the aspect of antonymy-triggered co-occurrence of metaphors in syntagmatic sequences.

As for the syntactic patterning, the analyzed sample, although small, suggests that the syntagmatically related antonyms whose senses belong to different conceptual domains may occur in syntactic frames beyond the characteristic ones identified in corpus-linguistic studies, especially including prepositionally related noun phrases, as in $(32,33,38,39,43)$.

At this point it should also be noted that the examples in this and in the previous two parts of the analysis have been attested in different areas of language use, including journalistic, literary and academic writing, as well as everyday communication - which also highlights the readiness with which the cognitive potential of antonymy is exploited for dynamic meaning construction. Unsurprisingly, the syntagmatic co-occurrence of antonyms whose senses belong to different conceptual domains features prominently 
in journalistic writing, especially in headlines, where this kind of dynamic meaning construal serves as a particular eye-catching strategy.

\section{Summary and concluding remarks}

Exploring different ways in which the lexical-semantic relation of antonymy lends itself to semantically creative exploitation in natural language use, this paper highlights the cognitive potential of antonymy for dynamic meaning construction, with particular regard to the sustainability of antonymy under asymmetric semantic extension. The findings reveal the proneness of canonical antonymy to be dynamically activated under semantic extension in the following respects: (i) the cognitively entrenched paradigmatic antonym relation is readily projectable to activate an extended sense which is generally not featured by one antonym pair member (with or without immediate contextual triggering by the explicit mention of the conventionalized counterpart sense); (ii) the cognitively entrenched paradigmatic antonym relation is readily exploited in idiom modification (with or without immediate contextual triggering by the explicit mention of the original idiomatic expression); (iii) canonical antonyms readily co-occur in discourse in their extended senses which belong to different conceptual domains. The versatile exploitation of the cognitive potential of antonymy in dynamic meaning construction also transpires from the fact that the attested linguistic data belong to different registers and genres, including journalistic, literary and academic writing, as well as everyday communication.

The analysis focuses on the English language, but its findings may be applicable cross-linguistically. With particular regard to the contrastive perspective, the findings may also find application in the fields of foreign language teaching and translation studies. With regard to the broader perspective of language-conceptualization interface, this paper may serve as a useful indicator for further interdisciplinary dialogue related to the study of lexical-semantic relations and the intricate interplay of language, cognition and creativity. 


\section{References}

Bolinger, D. (1977). Meaning and Form. London: Longman.

Croft, W. and D. A. Cruse (2004). Cognitive Linguistics. Cambridge: Cambridge University Press.

Cruse, D. A. (1986). Lexical Semantics. Cambridge: Cambridge University Press.

Cruse, D. A. (2004). Meaning in Language: An Introduction to Semantics and Pragmatics. $2^{\text {nd }}$ edition. Oxford: Oxford University Press.

Cruse, D. A. and P. Togia (1995). Towards a cognitive model of antonymy. Lexicology, 1, 113-141.

Deese, J. (1965). The Structure of Associations in Language and Thought. Baltimore, MD: The Johns Hopkins Press.

Deignan, A. (2005). Metaphor and Corpus Linguistics. Amsterdam/ Philadelphia: John Benjamins.

Fellbaum, C. (1995). Co-occurrence and antonymy. International Journal of Lexicography, 8, 281-303.

Fellbaum, C. (ed.) (1998). WordNet: An Electronic Lexical Database (with a preface by George Miller). Cambridge, MA: MIT Press.

Fillmore, C., P. Kay and M. C. O'Connor (1988). Regularity and idiomaticity in grammatical constructions: The case of let alone. Language, 64, 501-538.

Geeraerts, D. (2010). Theories of Lexical Semantics. Oxford: Oxford University Press.

Geeraerts, D. and H. Cuyckens (2010). The Oxford Handbook of Cognitive Linguistics. Oxford: Oxford University Press.

Goldberg, A. (2006). Constructions at Work. The Nature of Generalization in Language. Oxford/New York: Oxford University Press.

Gries, S. T. (2008). Phraseology and linguistic theory: A brief survey. In: S. Granger and F. Meunier (eds.), Phraseology: An Interdisciplinary Perspective, Amsterdam/Philadelphia: John Benjamins, 3-25.

Gross, D., U. Fischer and G. A. Miller (1988). Antonymy and the representation of adjectival meanings. Cognitive Science Laboratory Report 13, Dept. of Psychology, Princeton University.

Herrmann, D. J., R. Chaffin, G. Conti, D. Peters and P. H. Robbins (1979). Comprehension of antonymy and the generality of categorization models. Journal of Experimental Psychology: Human Learning and Memory, 5, 585-597.

Hlebec, B. (1979). Kontrastivna analiza prideva sa značenjem jedne dimenzije $\mathrm{u}$ savremenom engleskom i srpskohrvatskom jeziku. Doktorska disertacija. Filološki fakultet, Univerzitet u Beogradu. 
Hlebec, B. (1998). Connect Your Words. Belgrade: Trebnik.

Hlebec, B. (2008). Kolokacijska metoda semantičke analize (na primeru imenice pažnja). U: M. Radovanović i P. Piper (ur.), Semantička proučavanja srpskog jezika, Beograd: SANU, 65-75.

Hlebec, B. (2010). English Semantics for University Students. $2^{\text {nd }}$ edition. Belgrade: Čigoja.

Jones, S. (2002). Antonymy: A Corpus-Based Perspective. London: Routledge.

Jones, S., C. Paradis, M. L. Murphy and C. Willners (2007). Googling for 'opposites': A web-based study of antonym canonicity. Corpora, 2(2), $129-154$.

Jones, S., M. L. Murphy, C. Paradis and C. Willners (2012). Antonyms in English: Construals, Constructions and Canonicity. Cambridge: Cambridge University Press.

Jones, R. H. (ed.) (2016). The Routledge Handbook of Language and Creativity. Abingdon/New York: Routledge.

Justeson, J. S. and S. M. Katz (1991). Co-occurrences of antonymous adjectives and their contexts. Computational Linguistics, 17, 1-19.

Justeson, J. S. and S. M. Katz (1992). Redefining antonymy: The textual structure of a semantic relation. Literary and Linguistic Computing, 7, 176-184.

Kempson, R. M. (1977). Semantic Theory. Cambridge: Cambridge University Press.

Kennet, Y. N., D. Anaki and M. Faust (2014). Investigating the structure of semantic networks in low and high creative persons. Frontiers in Human Neuroscience, 8, 407. doi: 10.3389/fnhum.2014.00407

Kilgarriff, A. and G. Grefenstette (2003). Introduction to the special issue on the Web as corpus. Computational Linguistics, 29(3), 333-347.

Koller, V. (2004). Businesswomen and war metaphors: 'possessive, jealous and pugnacious?'. Journal of Sociolinguistics, 8/1, 3-22.

Kostić, N. (2013). Antonimija u diskursu: semantičko-pragmatička analiza. Podgorica: Univerzitet Crne Gore.

Kövecses, Z. (2002) Metaphor: A Practical Introduction. Oxford/New York: Oxford University Press.

Lakoff, G. (1993). The contemporary theory of metaphor. In: A. Ortony (ed.), Metaphor and Thought, $2^{\text {nd }}$ edition, Cambridge: Cambridge University Press, 202-251.

Lakoff, G. and M. Johnson (1980). Metaphors We Live By. Chicago: Chicago University Press. 
Landis, T., D. Herrmann and R. Chaffin (1987). Development differences in the comprehension of semantic relations. Zeitschrift für Psychologie, 195(2), 129-139.

Langlotz, A. (2006). Idiomatic Creativity: A Cognitive-linguistic Model of Idiom Representation and Idiom-variation in English. Amsterdam/ Philadelphia: John Benjamins.

Leech, G. (1981). Semantics: The Study of Meaning. $2^{\text {nd }}$ edition. Harmondsworth: Penguin Books.

Lehrer, A. (1985). Markedness and antonymy. Linguistics, 21, 397-429.

Lehrer, A. (2002). Paradigmatic relations of exclusion and opposition I: Gradable antonymy and complementarity. In: D. A. Cruse, F. Hundsnurcher, M. Job and P. R. Lutzeier (eds.), Handbook of Lexicology, Berlin: de Gruyter, 498-508.

Lyons, J. (1977). Semantics, Vol. 1. Cambridge: Cambridge University Press. Mel'čuk, I.A. (1995). Phrasemes in language and phraseology in linguistics. In: M. Everaert, E.-J. van der Linden, A. Schenk and R. Schreuder (eds.), Idioms: Structural and Psychological Perspectives, Hillsdale, NJ: Lawrence Erlbaum, 167-232.

Mettinger, A. (1994). Aspects of Semantic Opposition in English. Oxford: Clarendon Press.

Moon, R. (1998). Fixed Expressions and Idioms in English: A Corpus-Based Approach. Oxford: Oxford University Press.

Murphy, M. L. (2003). Semantic Relations and the Lexicon: Antonymy, Synonymy and Other Paradigms. Cambridge: Cambridge University Press.

Murphy, M. L. (2010). Lexical Meaning. Cambridge: Cambridge University Press.

Palmer, F. R. (1981). Semantics. $2^{\text {nd }}$ edition. Cambridge: Cambridge University Press.

Panther, K.-U. and G. Radden (eds.) (1999). Metonymy in Language and Thought. Amsterdam/ Philadelphia: John Benjamins.

Paradis, C. (2011). A dynamic construal approach to antonymy. In: E. Kitis, N. Lavidas, N. Topintzi, and T. Tsangalidis (eds.), Selected Papers from the 19th Symposium for Theoretical and Applied Linguistics, Thessaloniki: Aristotle University, 34-42.

Paradis, C. and C. Willners (2011). Antonymy: From convention to meaning-making. Review of Cognitive Linguistics, 9(2), 367-391. 
Paradis, C., C. Willners and S. Jones (2009). Good and bad opposites: Using textual and experimental techniques to measure antonym canonicity. The Mental Lexicon, 4(3), 380-429.

Philip, G. (2008). Reassessing the canon: 'Fixed phrases' in general reference corpora. In: S. Granger and F. Meunier (eds.), Phraseology: An Interdisciplinary Perspective, Amsterdam/Philadelphia: John Benjamins, 95-108.

Postman, L. and G. Keppel (1970). Norms of Word Association. New York: Academic Press.

Rasulić, K. (2004). Jezik i prostorno iskustvo. Beograd: Filološki fakultet.

Rasulić, K. (2010). Long time, no buzz: Fixed expressions as constructional frames. CogniTextes, Vol. 5, Grammaires en Construction(s)/Grammars in Construction(s), AFLiCo 3 special issue (eds. P. Grea and G. Desagulier). doi.org/10.4000/cognitextes.356

Rasulić, K. (2015). What's hot and what's not in English and Serbian: A contrastive view on the semantic extensions of temperature adjectives. In: M. Koptjevskaja Tamm (ed.), The Linguistics of Temperature, Amsterdam: John Benjamins, 254-299.

Rasulić, K. (2016). Exploring Semantic Relations. Belgrade: Faculty of Philology. Semino, E. (2008). Metaphor in Discourse. Cambridge: Cambridge University Press.

Sinclair, J.M. (1996). The search for units of meaning. TEXTUS IX (1), 71-106.

Ullmann, S. (1957). The Principles of Semantics. $2^{\text {nd }}$ edition. New York: Philosophical Library.

Willners, C. (2001). Antonyms in Context. Lund: Lund University.

Wray, A. (2002). Formulaic Language and the Lexicon. Cambridge: Cambridge University Press.

Received: 30 March 2019

Accepted for publication: 5 July 2020 
Katarina Rasulić: High Expectations and Low Blows: Antonymy and Dynamic...

Катарина Расулић

\section{ВИСОКА ОЧЕКИВАҢА И НИСКИ УДАРЦИ: АНТОНИМИЈА И ДИНАМИЧКО ГРАТЕЊЕ ЗНАЧЕЊА}

\section{Сажетак}

У радусе, на теоријској подлози когнитивне лингвистике, разматра когнитивни потенцијал лексичко-семантичке релације антонимије из перспективе динамичког грађења значења. Десет парова каноничких антонима у енглеском језику (high/low, long/short, broad/narrow, deep/shallow, thick/thin, heavy/light, hard/soft, large/small, fast/slow, hot/cold) испитано је са становишта начина на које се однос супротности значења њихових чланова динамички активира при семантичком проширењу, парадигматски и синтагматски, у семантички иновативним случајевима употребе. Анализа осветљава следеће видове динамичког грађења значења укојима антонимија служи као окидач: (1) доступност успаваних антонимских значења за активацију у контексту (нпр. shallow trouble); (2) могућност модификације идиоматских израза заменом члана антонимског пара (нпр. The bigger they come, the harder they fall $>$ The bigger they come, the softer they fall); (3) заједничко синтагматско јављање антонима у проширеним значењима која припадају различитим појмовним доменима (нпр. High hopes in low places). Теоријска разматрања тичу се когнитивне утврђености антонимије као моћног окидача динамичког грађења значења.

Кључне речи: антонимија, семантичко проширење, динамичко грађење значења, когнитивна лингвистика 